\title{
WORK ENGAGEMENT KARYAWAN PT. BUKIT ASAM PERSERO DITINJAU DARI SPIRITUALITAS
}

\author{
Ema Yudiani \\ Fakultas Psikologi UIN Raden Fatah Palembang \\ eyudiani@gmail.com
}

\begin{abstract}
This study aims to determine whether there is a relationship between work engagement and spirituality. The hypothesis proposed in this study is that there is a positive relationship between spirituality and work engagement. Subjects in this study were employees of PT. Bukit Asam, Persero amounted to 46 people. This study uses two different scales: Work Engagement Scale based on the dimensions of Work Engagement Schaufeli \& Bakker (2003), and Scale of Spirituality based on Milliman Spiritual dimension (2003). The results showed that there is a relationship between work engagement and spirituality in employees of PT. Bukit Asam, Persero. When employees spiritually discover deep meaning with their work, employees will show a high level of engagement by showing enthusiasm, dedication, and full concentration on the job.
\end{abstract}

Keywords: Spirituality, Work Engagement

\begin{abstract}
ABSTRAK
Tujuan penelitian ini adalah melihat hubungan antara work engagement dan spiritualitas. Hipotesis yang diajukan dalam penelitian ini adalah ada hubungan positif antara spiritualitas dan work engagement. Subjek dalam penelitian ini adalah karyawan PT. Bukit Asam, Persero berjumlah 46 orang. Penelitian ini menggunakan dua macam skala yaitu Skala Work Engagement berdasarkan dimensi Work Engagement Schaufeli \& Bakker (2003), dan Skala Spiritualitas berdasarkan dimensi Spiritualitas Milliman (2003). Hasil penelitian menunjukkan bahwa terdapat hubungan antara work engagement dan spiritualitas pada karyawan PT. Bukit Asam, Persero. Ketika karyawan secara spiritual menemukan makna yang dalam dengan pekerjaannya maka karyawan akan memperlihatkan tingkat engagement yang tinggi dengan menunjukkan semangat, dedikasi, dan konsentrasi penuh terhadap pekerjaan.
\end{abstract}

Kata Kunci: Spiritualitas, Work Engagement

\section{PENDAHULUAN}

Batubara merupakan bahan bakar fosil yang menjadi sumber energi terpenting untuk pembangkitan listrik dan berfungsi sebagai bahan bakar pokok untuk produksi baja dan semen. Sejak tahun 2005, Indonesia adalah salah satu produsen dan eksportir batubara terbesar di dunia. Seiring dengan perjalanan waktu, situasi industri batubara yang menguntungkan ini berubah drastis pada saat terjadi krisis keuangan global pada tahun 2008 ketika harga-harga komoditas menurun begitu cepat. Perlambatan pertumbuhan ekonomi global berimbas pada penurunan harga batubara nasional dari awal tahun 2011 (http://www.indonesia-investments.com).

Kondisi tersebut sangat memberatkan pelaku industri batubara nasional. Berdasarkan sumber dari Asosiasi Pertambangan Batubara Indonesia (APBI, dalam Annual Report PTBA, 2015), krisis harga batubara global telah menimbulkan kerugian bagi $70 \%$ pertambangan batubara di Indonesia, bahkan $40 \%$ pemain industri batubara sudah menutup usahanya. Kecenderungan penurunan harga batubara yang terus berlangsung mengkhawatirkan, 
karena akan semakin banyak pelaku industri yang merugi dan menutup usahanya.

Menghadapi situasi sulit ini, PT. Bukit Asam, Persero (disingkat PTBA) sebagai salah satu perusahaan tambang terbesar di Indonesia yang berlokasi di Sumatera Selatan menyikapi kondisi ini dengan melakukan efisiensi secara optimal melalui berbagai terobosan dan langkah-langkah strategis. Upaya dan kerja keras PTBA pada tahun 2015 membuahkan hasil yang gemilang dengan memberikan kontribusi positif terhadap pendapatan PTBA. Secara umum PTBA dapat membukukan kinerja yang positif dan cenderung meningkat baik dari aspek operasional maupun aspek keuangan.

Pencapaian-pencapaian yang dialami oleh PTBA tentu saja tidak akan dapat terwujud tanpa dukungan banyak pihak yang meliputi karyawan, pelanggan, dan investor. Manusia dalam konteks organisasi disebut sebagai karyawan, merupakan sumber daya yang paling utama dalam organisasi karena kelangsungan hidup dan keberhasilan suatu organisasi tergantung pada peran karyawan. Menurut Simamora (2004), aset organisasi paling penting yang harus dimiliki oleh perusahaan dan sangat diperhatikan oleh manajemen adalah aset manusia yang dalam hal ini adalah karyawan.

Muncul satu pertanyaan menarik terkait dengan pencapaian PTBA saat ini, bagaimana PTBA mengelola dan memanajemen karyawannya agar dapat bersinergi mendukung program-program pengembangan untuk menghadapi krisis penurunan harga batu bara. Apa saja yang dilakukan perusahaan sehingga tetap dapat menampilkan well performed di tengah badai penurunan harga batu bara yang melanda sehingga tetap dapat survived. Terkait dengan hal tersebut, peneliti melakukan studi pendahuluan dengan menggunakan metode wawancara dengan Senior Manager SDM PTBA serta melakukan Focus Group
Discussion (FGD) pada 9 (sembilan) orang karyawan.

Hasil studi pendahuluan menemukan bahwa pada saat perusahaan mengalami krisis harga batubara karyawan tetap memiliki engagement dengan perusahaan dan pekerjaannya. Karyawan merasa engaged dengan pekerjaannya yang diekspresikan dalam perilaku tidak ingin menunda-nunda penyelesaian pekerjaan dan ingin memahami secara mendalam job description yang dibebankan kepadanya. Dalam bekerja, tidak hanya kognisi dan perilaku kerja saja yang terlibat tetapi juga kondisi emosional (perasaan) sehingga kondisi ini memunculkan kondisi dimana karyawan merasa menikmati pekerjaan dan merasa dihargai serta dipercayai sebagai bentuk dukungan dari atasan. Kondisi keterlibatan ini membuat karyawan tidak hanya memikirkan perkembangan karir pribadi namun juga ikut memikirkan perkembangan perusahaan secara umum.

Work engagement karyawan di perusahaan tidak akan terbentuk dengan sendirinya. Terdapat beberapa faktor personal maupun organisasi yang berpengaruh terhadap work engagement. Dalam penelitian ini peneliti memilih faktor spritualitas sebagai faktor personal yang mempengaruhi work engagement. Spritualitas menjadi salah satu tema penting di berbagai negara dan menjadi perhatian luas bagi segenap masyarakat, baik anggota masyarakat umum, perusahaan, dan para ahli. Perkembangan selanjutnya menunjukkan bahwa perusahaan mendorong pengembangan spiritualitas karena mereka percaya adanya pengaruh positif terhadap kehidupan organisasi (Neal dan Biberman, 2004). Spiritualitas di tempat kerja berpengaruh positif terhadap kinerja organisasi, baik dalam aspek kualitas maupun kuantitas (Heaton, dkk., 2004; King \& Crowther, 2004). 
Tingkat spiritualitas individu karyawan dalam organisasi dapat berpengaruh pada kualitas psikologis atau kekuatan karakter, pendekatan dalam berinteraksi dengan orang lain, dan kinerjanya (Samiyanto, 2011). Tema tentang kekuatan karakter individu merupakan domain yang mendapatkan perhatian besar saat ini melalui psikologi positif (Compton, 2005; Seligman, 2005; Seligman, dkk., 2005). Work engagement merupakan salah satu konstruk yang dikembangkan oleh psikologi positif dalam organisasi. Spiritualitas akan menghasilkan hal-hal positif bagi karyawan dan perusahaan. Litszey (2003) berpendapat bahwa mengintegrasikan spiritualitas di tempat kerja akan membuat karyawan merasakan makna dan perasaan bertujuan dalam kehidupannya termasuk kehidupan kerjanya. Kebermaknaan yang dirasakan karyawan ini senada dengan dimensi dedication dalam work engagement. Ketika karyawan merasa bahwa pekerjaan memberikan makna khusus bagi dirinya maka akan muncul adanya antusiasme, identifikasi yang kuat dengan pekerjaan, bangga terhadap pekerjaannya, dan terinspirasi dan tertantang oleh pekerjaanya yang dimilikinya, sehingga pada akhirnya akan berpengaruh terhadap kinerjanya.

Dengan demikian berdasarkan uraian di atas, peneliti melihat adanya pengaruh spiritualitas karyawan terhadap work engagement. Karyawan yang memiliki tingkat spiritualitas yang tinggi akan menjadi engaged dengan pekerjaannya karena merasa menemukan makna yang berarti dalam kehidupannya. Kebermaknaan ini juga yang kemudian memunculkan keterlibatan dalam pekerjaan tidak hanya dari secara kognitif saja tetapi juga secara afeksi dan perilaku. Sepanjang sepengetahuan peneliti, selama ini belum ada penelitian yang menghubungkan variabel spiritualitas dengan work engagement, sehingga penelitian ini akan melihat keterkaitan kedua variabel tersebut.

\section{LANDASAN TEORI}

\section{Work Engagement}

Di masa lalu, kajian-kajian dalam psikologi kebanyakan lebih menekankan pada aspek-aspek negative dari perilaku individu, seperti malfungsi, kelemahan, dan patologi (Schaufeli dan Salanova, 2007). Dewasa ini, berkembang pendekatan yang memandang individu secara lebih optimis yaitu Psikologi Positif, yang selain memusatkan perhatian pada kelemahan-kelemahan individu juga pada kekuatan atau kelebihan-kelebihan individu, optimalisasi fungsi-fungsi psikologis dan well-being (Seligman dan Csikszentmihalyi, 2000). Kecenderungan pandangan psikologi positif ini memunculkan konsep Work Engagement.

Berbagai penelitian dilakukan untuk menguji sebaba-sebab dan akibat-akibat dari engagement ini, beberapa penelitian mencoba mengidentifikasi berbagai metode untuk meningkatkan engagement yang difokuskan pada apa yang dapat diberikan oleh organisasi pada para karyawannya sehubungan dengan engagement ini. Engagement sangat berkaitan erat dengan lingkungan organisasi. Hubungan yang kuat antara engaged employees dengan perilaku kerja produktif telah teridentifikasi (Harter, Schimdt, \& Hayes, 2002).

Beberapa tahun belakangan ini, minat untuk mengkaji work engagement tampak semakin besar, beberapa peneliti menegaskan bahwa work engagement atau employee engegement dapat memprakirakan produktivitas karyawan, keberhasilan organisasi, dan kinerja finansial (Bates, 2004).

Dengan demikian, perkembangan penelitian ini menyiratkan adanya kecenderungan menuju psikologi positif yang lebih menekanan pada kekuatan individu dan optimalisasi fungsi-fungsi psikologis dibanding kelemahan-kelemahan dan 
malfunctioning (Seligman dan Csikszentmihalyi, 2000).

Work engagement merupakan sebuah konsep yang luas, yang terdiri dari berbagai konstruk multidimensional dan pengalaman, yang terdiri dari afeksi, kognisi, dan perilaku, karena pada individu yang engage, mereka memiliki level energi yang tinggi dan antusias terlibat dalam pekerjaan mereka. (Bakker, Schaufeli, Leiter \& Taris, 2008). Para individu yang engage ini tidak hanya bersemangat dan berenergi, mereka juga menikmati pekerjaan memiliki keterlibatan dengan pekerjaan, dan melihat masalah sebagai suatu hal yang menantang, serta sering kali merasa 'tenggelam' dalam pekerjaannya.

Work engagement merupakan hal yang bersifat individual. Setiap individu akan memiliki tingkat work engagement yang berbeda-beda sesuai dengan level trait atau pandangan seseorang yang akan berbeda satu sama lain (Bakker, Arnold \& Leiter, Michael, 2010). Semakin banyak aspek-aspek dalam pekerjaan yang sesuai dengan keinginan individu semakin tinggi juga level engagement-nya.

Work engagement (atau bisa disebut juga employee engagement) merupakan suatu konsep yang secara umum dilihat sebagai pengaturan discretionary effort, yaitu ketika karyawan memiliki pilihan, mereka akan bertindak untuk kepentingan organisasi. Seseorang engage-worker adalah orang yang sepenuhnya terlibat dan antusias terhadap pekerjaannya.

Menurut Schaufeli \& Bakker (2003) Terdapat tiga dimensi yang merupakan karakteristik dari work engagement, yaitu: 1) Vigour (energi), merupakan tingginya energinya yang dikeluarkan, kemauan untuk memeberikan usaha yang bisa dipertimbangkan, dan menunjukkan ketekunan ketika menghadapi kesulitan; 2) Dedication yaitu antusiasme, inspirasi, dan kebanggaan; identifikasi yang kuat terhadap suatu pekerjaan; dan 3) Absorption yaitu konsentrasi penuh, fokus terhadap pekerjaan. Absorption memiliki karakteristik berupa keterlibatan penuh karyawan pada pekerjaannya dengan berkonsentrasi penuh dan menyenangai pekerjaannya, sehingga merasa waktu berjalan dengan cepat dan sulit untuk memisahkan dari dari pekerjaannya.

\section{Spiritualitas}

Ashmos \& Duchon (2000) mengartikan spiritualitas di tempat kerja sebagai suatu pengenalan bahwa karyawan memiliki "kehidupan dalam" yang memelihara dan dipelihara oleh pekerjaan yang bermakna yang mengambil tempat dimana dalam konteks ini adalah komunitas. Hal tersebut ditekankan bahwa spiritualitas di tempat kerja bukan tentang agama, walaupun orang terkadang mengekspresikan kepercayaan agama mereka di tempat kerja.

Mitroff dan Denton (1999) dalam Milimman, dkk (2003) menjelaskna bahwa spiritualitas di tempat kerja melibatkan upaya untuk menemukan tujuan akhir seseorang dalam hidup, mengmbangkan hubungan yang kuat antar rekan kerja yang terkait dengan pekerjaan, dan memiliki konsistensi dan keselarasan antara keyakinan inti seseorang dan nilai-nilai organisasi mereka.

Milliman, dkk., (2003) menjelaskan bahwa spiritualitas ditempat kerja memiliki tiga dimensi yang membentuknya, yaitu meaningful work, sense of community, dan value alignment. Dimensi meaningfull work menunjukkan seberapa besar interaksi seorang karyawan dengan aktifitas kerjanya sehari-hari pada level individu. Spiritualitas di tempat kerja pada dimensi ini mengisyaratkan bahwa karyawan memilki motivasi personal dan keinginan untuk terlibat dengan aktfitas kerjanya sebagai bagian yang bermakna bagi hidupnya (Hawley, 1993). Dimensi sense of community menunjukkan interaksi atau 
hubungan yang dalam antara seorang karyawan dengan orang-orang di komunitasnya yang dalam hal ini organisasi (Ashmos \& Ducon, 2000). Karyawan merasakan adanya keterhubungan dirinya dengan orang lain dan hubungan tersebut melibatkan kehidupan batin dirinya dan orang lain (Maynard, 1992). Pada level ini terdapat hubungan antara keterlibatan mental, emosional, dan spiritual pada karyawan yang bekerja dalam tim atau kelompok (Neal \& Bennet, 2000). Dimensi value alignment mengukur seberapa jauh pengalaman individu dapat menunjukkan keselarasan antara yang dirasakan dengan visi dan misi organisasi (Milliman, Czaplewski and Ferguson, 2003). Dimensi ini menunjukkan bahwa karyawan yang bekerja pada suatu organisasi akan menunjukkan adanya integritas yang kuat, praktek perilaku etis, dan selalu ingin memberikan kontribusi yang besar untuk organisasinya.

Perusahaan yang menerapkan spiritualitas di tempat kerja, akan menjadikan karyawannya merasa terhubung dan bermakna di tempat kerja, karyawan akan tampil lebih baik, muncul lebih sering, dan memberikan kontribusi yang lebih terhadap suasana yang lebih baik di tempat kerja. Selanjutnya, karyawan ingin lebih mengontrol pekerjaan mereka, lebih menyeimbangkan kehidupan kerja, dan karyawan akan lebih meningkatkan makna dalam pekerjaan mereka (Gull \& Doh, dalam Khasawneh, 2011).

Martin dkk (dalam Rego \& Cunha,
2008) menyatakan bahwa penerapan spiritualitas di tempat kerja akan merangsang karyawan untuk membentuk persepsi yang lebih positif terhadap organisasi sehingga karyawan akan mendapatkan perubahan dan mencapai penyesuaian yang lebih baik melalui pekerjaan dengan kepuasan yang lebih tinggi, berkomitmen terhadap organisasi, kesejahteraan organisasi, dan rendahnya keinginan untuk melakukan turn over serta ketidak hadiran.

\section{Hipotesis Penelitian}

"Ada hubungan positif antara work engagement dengan spiritualitas. Semakin tinggi spiritualitas maka semakin tinggi work engegement. Semakin rendah spiritualitas, maka semakin rendah pula work engagement.

\section{METODE PENELITIAN}

\section{Jenis Penelitian}

Penelitian ini merupakan penelitian kuantitatif yang bertujuan untuk mencari hubungan antara dua variabel (korelasional).

\section{Variabel Penelitian}

1. Variabel bebas : Spiritualitas

2. Variabel terikat : Work Engagement

\section{Subjek Penelitian}

Subjek penelitian ini adalah karyawan PT. Bukit Asam, Persero yang berjumlah 46 orang dengan karakteristik sebagai berikut:

1. Karyawan tetap PT. Bukit Asam, Persero

2. Masa kerja minimal 1 tahun

3. Laki-laki dan perempuan

\section{Metode Pengumpulan Data}

Menurut sumbernya, data yang digunakan dalam penelitian ini adalah skala pengukuran atau alat pengambilan data langsung pada subjek sebagai sumber informasi yang dicari yang diperoleh melalui skala psikologi yakni Skala Spiritualitas dan Skala Work Engagement.

\section{Skala Work Engagement}

Skala Work Engagement ini digunakan untuk mengetahui tingkat work engagement dari subjek penelitian. Skala ini mengukur work engagement berdasarkan dimensi work engagement dari Schaufeli \& Bakker (2003), skala ini terdiri dari 45 butir pernyataan 
secara positif (favourable) dan negatif (favourable).

Pemberian nilai dalam skala ini menggunakan model Likert yang telah diadaptasi dengan empat alternatif jawaban, yaitu Sangat Sesuai (SS), Sesuai (S), Tidak Sesuai (TS) dan Sangat Tidak Sesuai (STS). Jawaban SS diberi skor 4, S diberi skor 3, TS diberi skor 2, dan STS diberi skor 1. Nilai total diperoleh dari penjumlahan skor keseluruhan aitem, dimana semakin tinggi nilai total yang didapat maka semakin tinggi tingkat work engagement dan semakin rendah nilai total yang didapat maka semakin rendah tingkat work engagement.

Setelah dilakukan ujicoba, dari 46 butir terdapat 18 butir pernyataan yang gugur dan 27 butir pernyataan yang valid dengan nilai $r=0,850$. Pada Tabel 1 dan 2 berikut ini adalah distribusi butir skala sebelum dan sesudah uji coba.

Tabel 1.

Distribusi Butir Skala Work Engagement Sebelum Uji Coba

\begin{tabular}{|l|l|c|c|cr|}
\hline \multirow{2}{*}{ NO } & \multirow{2}{*}{ DIMENSI } & \multicolumn{2}{|c|}{ SEBARAN ITEM } & \multirow{2}{*}{ JUMLAH } \\
\cline { 3 - 4 } & & Favourable & Unfavourable & \\
\hline 1. & Vigour & $1-2-3-4-5-6-$ & $9-10-11-12-$ & 15 & nil \\
& & $7-8$ & $13-14-15$ & & ada \\
\hline 2. & Dedication & $16-17-18-$ & $24-25-26-27-$ & 15 & ses \\
& & $19-20-21-$ & $28-29-30$ & & \\
& & $22-23$ & & & \\
\hline 3. & Absorption & $31-32-33-$ & $39-40-41-42-$ & 15 \\
& & $34-35-36-$ & $43-44-45$ & & \\
& & $37-38$ & & & \\
\hline
\end{tabular}

JUMLAH 20 24 45

Tabel 2.

Distribusi Butir Skala Work Engagement Setelah Uji Coba

\begin{tabular}{|c|c|c|c|c|}
\hline \multirow[t]{2}{*}{$\mathrm{NO}$} & \multirow[t]{2}{*}{ DIMENSI } & \multicolumn{2}{|c|}{ SEBARAN ITEM } & \multirow[t]{2}{*}{ JUMLAH } \\
\hline & & Favourable & Unfavourable & \\
\hline 1. & Vigour & $2-5-6-7$ & $\begin{array}{c}9-10-11-12-14- \\
15\end{array}$ & 10 \\
\hline 2. & Dedication & $\begin{array}{c}16-19-20- \\
21\end{array}$ & $26-27-30$ & 7 \\
\hline 3. & Absorption & $\begin{array}{c}\text { 32-34-35- } \\
38\end{array}$ & $\begin{array}{c}39-40-41-42- \\
44-45\end{array}$ & 10 \\
\hline \multicolumn{2}{|c|}{ JUMLAH } & 12 & 15 & 27 \\
\hline
\end{tabular}

2. Skala Spiritualitas

Skala Spiritualitas digunakan untuk mengetahui tingkat spiritualitas dari subjek penelitian. Skala ini mengukur spiritualitas berdasarkan dimensi spiritualitas dari Milliman (2003). Skala ini terdiri dari 45 butir pernyataan secara positif (favourable) dan negatif (favourable).

Pemberian nilai dalam skala ini menggunakan model Likert yang telah diadaptasi dengan empat alternatif jawaban, yaitu Sangat Sesuai (SS), Sesuai (S), Tidak Sesuai (TS) dan Sangat Tidak Sesuai (STS). Jawaban SS diberi skor 4, S diberi skor 3, TS diberi skor 2, dan STS diberi skor 1. Nilai total diperoleh dari penjumlahan skor keseluruhan aitem, dimana semakin tinggi nilai total yang didapat maka semakin tinggi tingkat spiritualitas dan semakin rendah nilai total yang didapat maka semakin rendah tingkat spiritualitasnya.

Setelah dilakukan ujicoba, dari 45 ytir terdapat 15 butir pernyataan yang gugur an 30 butir pernyataan yang valid dengan iilai $r=0,880$. Pada Tabel 3 dan 4 berikut ini adalah distribusi butir skala sebelum dan esudah uji coba.

Tabel 3.

Distribusi Butir Skala Spiritualitas Sebelum Uji Coba 


\begin{tabular}{|l|l|c|c|c|}
\hline \multirow{2}{*}{ NO } & \multirow{2}{*}{ DIMENSI } & \multicolumn{2}{|c|}{ SEBARAN ITEM } & \multirow{2}{*}{ JUMLAH } \\
\cline { 3 - 4 } & & Favourable & Unfavourable & \\
\hline 1. & Meaningfull & $1-2-3-4-5-$ & $9-10-11-12-$ & 15 \\
& work & $6-7-8$ & $13-14-15$ & \\
\hline 2. & Sense of & $16-17-18-$ & $24-25-26-27-$ & 15 \\
& community & $19-20-21-$ & $28-29-30$ & \\
& & $22-23$ & & \\
\hline 3. & Value & $31-32-33-$ & $39-40-41-42-$ & 15 \\
& Alignment & $34-35-36-$ & $43-44-45$ & \\
& & $37-38$ & & \\
\hline \multicolumn{2}{r}{ JUMLAH } & 20 & 24 & 45 \\
\hline
\end{tabular}

Tabel 4.

Distribusi Butir Skala Spiritualitas

Setelah Uji Coba

\begin{tabular}{|l|l|c|c|c|}
\hline \multirow{2}{*}{ NO } & \multirow{2}{*}{ DIMENSI } & \multicolumn{2}{|c|}{ SEBARAN ITEM } & \multirow{2}{*}{ JUMLAH } \\
\cline { 3 - 4 } & & Favourable & Unfavourable & \\
\hline 1. & Meaningfull & $2-3-5-6-7$ & $9-11-12-13-$ & 10 \\
& work & & 14 & \\
\hline 2. & Sense of & $18-19-20-$ & $24-25-26-27-$ & 10 \\
& community & 22 & $29-30$ & \\
\hline 3. & Value & $31-32-33-$ & $39-40-41-43-$ & 10 \\
& Alignment & $34-36$ & 45 & 30 \\
\hline \multicolumn{2}{|c|}{ JUMLAH } & 15 & 15 & 30 \\
\hline
\end{tabular}

\section{Metode Analisis Data}

Pengujian hipotesis dilakukan dengan teknik product moment dari Pearson dengan alasan bahwa penelitian ini bertujuan mencari korelasi antara dua variabel penelitian, yaitu spiritualitas dan Work Engagement pada karyawan dan data yang diperoleh berbentuk interval. Seluruh perhitungan dilakukan dengan komputer menggunakan program SPSS 17.0 for Windows.

\section{HASIL PENELITIAN}

Deskripsi Subjek Penelitian

Tabel 5

Jenis Kelamin

\begin{tabular}{|c|l|c|c|}
\hline No & \multicolumn{1}{|c|}{$\begin{array}{c}\text { Jenis } \\
\text { Kelamin }\end{array}$} & Jumlah & $\begin{array}{c}\text { Persentase } \\
(\boldsymbol{\%})\end{array}$ \\
\hline 1 & Laki-laki & 36 & 78,26 \\
\hline 2 & Perempuan & 10 & 21,73 \\
\hline & Total & 46 & 100 \\
\hline
\end{tabular}

Tabel 6

\begin{tabular}{|c|c|c|c|}
\multicolumn{5}{|c}{ Usia } \\
\hline No & Usia & $\begin{array}{c}\text { Jumla } \\
\mathbf{h}\end{array}$ & $\begin{array}{c}\text { Persentase } \\
(\boldsymbol{\%})\end{array}$ \\
\hline 1 & $<26$ & 4 & 8,7 \\
\hline 2 & $26-30$ & 6 & 13,04 \\
\hline 3 & $31-35$ & 9 & 19,56 \\
\hline 4 & $36-40$ & 13 & 28,26 \\
\hline 5 & $41-50$ & 11 & 23,91 \\
\hline 6 & $46-50$ & 3 & 6,52 \\
\hline 7 & $<70$ & 0 & 0 \\
\hline & Total & 46 & 100 \\
\hline
\end{tabular}

Tabel 7

Kategorisasi Jabatan

\begin{tabular}{|c|l|c|c|}
\hline No & \multicolumn{1}{|c|}{ Jabatan } & Jumlah & $\begin{array}{c}\text { Persentas } \\
\mathbf{e}(\%)\end{array}$ \\
\hline 1 & $\begin{array}{l}\text { Manajer } \\
\text { Utama/Fungsional } \\
\text { Utama }\end{array}$ & 3 & 6,52 \\
\hline 2 & $\begin{array}{l}\text { Manajer } \\
\text { Madya/Fungsional } \\
\text { Madya }\end{array}$ & 5 & 10,86 \\
\hline 3 & $\begin{array}{l}\text { Manajer } \\
\text { Muda/Fungsional } \\
\text { Muda }\end{array}$ & 21 & 45,65 \\
\hline 4 & $\begin{array}{l}\text { Penyelia/Fungsion } \\
\text { al Pratama }\end{array}$ & 15 & 32,60 \\
\hline 5 & PelaksanaTerampil & 2 & 4,34 \\
\hline & Total & 46 & 100 \\
\hline
\end{tabular}

Tabel 8

Masa Kerja

\begin{tabular}{|c|c|c|c|}
\hline No & $\begin{array}{c}\text { Masa } \\
\text { Kerja }\end{array}$ & Jumlah & $\begin{array}{c}\text { Persentase } \\
(\%)\end{array}$ \\
\hline 1 & $<5$ tahun & 2 & 4,34 \\
\hline 2 & $\begin{array}{c}5-10 \\
\text { tahun }\end{array}$ & 12 & 26,08 \\
\hline 3 & $\begin{array}{c}11-15 \\
\text { tahun }\end{array}$ & 19 & 41,30 \\
\hline 4 & $\begin{array}{c}16-19 \\
\text { tahun }\end{array}$ & 8 & 17,39 \\
\hline
\end{tabular}




\begin{tabular}{|c|c|c|c|}
\hline 5 & $\begin{array}{c}<20 \\
\text { tahun }\end{array}$ & 5 & 10,9 \\
\hline & Total & 46 & 100 \\
\hline
\end{tabular}

Subjek penelitian kemudian dikelompokkan ke dalam tiga kategori pada masing-masing variabel, yang dapat dilihat pada tabel-tabel berikut ini.

\section{Tabel 9}

\section{Kategorisasi Variabel Etos Kerja Islami}

\begin{tabular}{|c|c|c|c|c|}
\hline Satuan SD & Skor & Kategori & Frekuensi & $\%$ \\
\hline$X \leq-1,3$ & $X \leq 54$ & Rendah & 0 & 0 \\
\hline$-0,3<X \leq+0,3$ & $54<X \leq 81$ & Sedang & 14 & 30,43 \\
\hline$+0,3<\mathrm{X}$ & $81<X$ & Tinggi & 32 & 69,56 \\
\hline \multicolumn{3}{|c|}{ Jumlah } & 46 & 100 \\
\hline
\end{tabular}

Tabel 10

Kategorisasi Variabel Religiusitas

\begin{tabular}{|c|c|c|c|c|}
\hline Satuan SD & Skor & Kategori & Frekuensi & $\%$ \\
\hline$X \leq-1,3$ & $X \leq 60$ & Rendah & 0 & 0 \\
\hline$-0,3<X \leq+0,3$ & $60<X \leq 90$ & Sedang & 11 & 23,91 \\
\hline$+0,3<\mathrm{X}$ & $90<X$ & Tinggi & 35 & 76,08 \\
\hline \multicolumn{3}{|c|}{ Jumlah } & 46 & 100 \\
\hline
\end{tabular}

\section{Uji Asumsi}

\section{Uji Normalitas}

Hasil uji normalitas terhadap data kedua skala, menunjukkan bahwa:

1. Data yang berasal dari skala Work Engagement mempunyai koefisien $\mathrm{KS}-\mathrm{Z}$ sebesar 0,692 dengan $\mathrm{p}=0,752(\mathrm{p}>$ $0.05)$.

2. Data yang berasal dari skala Spiritualitas mempunyai koefisien KS-Z sebesar 0,525 dengan $\mathrm{p}=0,945(\mathrm{p}>0.05)$.

Hasil uji normalitas ini menunjukkan bahwa data dari kedua skala tersebut memiliki sebaran normal.

\section{Uji Linieritas}

Hasil uji linieritas menunjukkan bahwa antara etos kerja islami dengan religiusitas memiliki koefisien $\mathrm{F}$ sebesar 29,446 dengan nilai $\mathrm{p}=0.000(\mathrm{p}<0.01)$. Hasil uji linieritas menunjukkan bahwa hubungan antara kedua variabel telah memenuhi asumsi linieritas.

\section{Uji Hipotesis}

Hasil analisa menunjukkan koefisien korelasi $(r)$ sebesar 0.633 dengan $\mathrm{p}=0.000(\mathrm{p}$ $<0.01$ ) pada uji satu sisi (two-tailed). Dari hasil tersebut dapat dilihat bahwa terdapat korelasi positif yang sangat signifikan antara spiritualitas dengan work engagement. Hal ini dapat diartikan bahwa ada hubungan antara spiritualitas dengan work engagement pada karyawan.

\section{DISKUSI}

Penelitian ini dimaksudkan untuk mencari hubungan antara spiritualitas dan work engagement pada karyawan PTBA. Berdasarkan analisis statistik yang telah penulis lakukan sebelumnya, diperoleh hasil yang menunjukkan adanya hubungan yang positif antara spiritualitas dan work engagement pada karyawan PTBA. Artinya, spiritualitas seorang karyawan berhubungan dengan work engagement yang dimilikinya dalam melaksanakan aktivitas kerja. Karyawan yang memiliki tingkat spiritualitas yang tinggi akan menjadi engaged dengan pekerjaannya karena merasa menemukan makna yang berarti dalam kehidupannya. Kebermaknaan ini juga yang kemudian memunculkan keterlibatan dalam pekerjaan tidak hanya dari secara kognitif saja tetapi juga secara afeksi dan perilaku.

Temuan dari hasil penelitian ini dapat dipahami bahwa seorang karyawan yang memiliki spiritualitas yang tinggi maupun sebaliknya berpengaruh pada work engagement pada karyawan PTBA. Samiyanto (2011) mengatakan bahwa tingkat spiritualitas karyawan dalam organisasi dapat berpengaruh pada kualitas psikologis atau 
kekuatan karakter, pendekatan dalam berinteraksi dengan orang lain, dan kinerjanya. Tema tentang kekuatan karakter individu merupakan domain yang mendapatkan perhatian besar saat ini melalui psikologi positif (Compton, 2005; Seligman, 2005; Seligman, dkk., 2005). Work engagement merupakan salah satu konstruk yang dikembangkan oleh psikologi positif dalam organisasi.

Spiritualitas akan menghasilkan halhal positif bagi karyawan dan perusahaan. Litszey (2003) berpendapat bahwa mengintegrasikan spiritualitas di tempat kerja akan membuat karyawan merasakan makna dan perasaan bertujuan dalam kehidupannya termasuk kehidupan kerjanya. Kebermaknaan yang dirasakan karyawan ini senada dengan dimensi dedication dalam work engagement. Ketika karyawan merasa bahwa pekerjaan memberikan makna khusus bagi dirinya maka akan muncul adanya antusiasme, identifikasi yang kuat dengan pekerjaan, bangga terhadap pekerjaannya, dan terinspirasi dan tertantang oleh pekerjaanya yang dimilikinya, sehingga pada akhirnya akan berpengaruh terhadap kinerjanya.

Selain menunjukkan adanya hubungan yang positif antara spiritualitas dan work engagement pada karyawan, penelitian ini juga menunjukkan hasil bahwa subjek penelitian secara umum memiliki tingkat spiritualitas yang tinggi dan memiliki tingkat work engagement yang tinggi. Ketika bekerja, karyawan PT. Bukit Asam, Persero merasa dapat mengembangkan potensi diri, karyawan memiliki keterhubungan dengan sesama karyawan dan atasan yang ditunjukkan dengan adanya suasana kekeluargaan, karyawan juga dapat memaknai bahwa bekerja merupakan suatu bentuk ibadah kepada Tuhan yang menunjukkan keterhubungannya dengan Sang Pencipta, sehingga pada akhirnya karyawan merasa bahwa bekerja memiliki arti penting yang membawa perubahan pada kehidupan pribadinya. Kondisi ini menunjukkan bahwa spritualitas sebagai bentuk kesadaran akan kebutuhan kebermaknaan dan tujuan hidup mendorong seseorang memperbaharui pandangannya tentang organisasi dan kerja. Kerja dipandang tidak hanya mencari kebutuhan ekonomi semata tetapi juga bagian dari pemenuhan kebutuhan kebermaknaan dan tujuan yang lebih jauh, sehingga tempat kerja merupakan lingkungan bagi pertumbuhan pribadinya secara utuh (Srinivasan, 2003).

Pada akhirnya, penulis menyadari bahwa apa yang dilakukan dalam penelitian ini merupakan bagian dari sebuah proses untuk memahami fenomena religiusitas dan etos kerja islami secara komprehensif. Namun demikian penulis menyadari bahwa dalam pelaksanaan penelitian Ini masih terdapat informasi yang belum mampu terungkap secara optimal. Beberapa keterbatasan penelitian yang dapat penulis rumuskan. Pertama, dalam proses penyusunan skala dimana masih ditemukan adanya butir-butir pernyataan yang mengandung social desirability, sehingga membuat subjek memilih jawaban yang sekiranya dapat diterima oleh orang lain, bukan karena kenyataan yang ada pada diri karyawan.

Kedua, keterbatasan penelitian ini juga ditemui pada sedikitnya jumlah subjek yang berhasil penulis himpun untuk diminta kesediaanya sebagai subjek penelitian. Menurut pemahaman penulis dari apa yang telah penulis temukan di lapangan, minimnya skala yang kembali terjadi karena subjek memiliki keterbatasan meluangkan waktu mengisi skala sehingga beberapa skala yang telah tersebar tidak kembali, subjek memiliki prioritas pekerjaan yang cukup padat sehingga ada indikasi penelitian ini belum termasuk sebagai prioritas utama subjek.

Ketiga, dalam pengisian skala ini penulis berupaya pengambilan data langsung. 
Namun sebagian subjek meminta skala penelitian ditinggal dan diambil lagi pada hari yang telah ditentukan dengan alasan keterbatasan waktu subjek. Walaupun demikian sebagian subjek lainnya bersedia didampingi dalam pengisian skala. Diharapkan dalam pengambilan data berikutnya pengisian skala dapat diisi secara langsung sehingga data yang terhimpun lebih akurat.

\section{SIMPULAN}

Kesimpulan yang diperoleh dari penelitian ini adalah ada hubungan yang positif antara spiritualitas dan work engagement pada karyawan PTBA. Semakin tinggi spiritualitas maka semakin tinggi work engegement. Semakin rendah spiritualitas, maka semakin rendah pula work engagement. Artinya, spiritualitas seorang karyawan berhubungan dengan work engagement yang dimilikinya dalam melaksanakan aktivitas kerja. Karyawan yang memiliki tingkat spiritualitas yang tinggi akan menjadi engaged dengan pekerjaannya karena merasa menemukan makna yang berarti dalam kehidupannya. Kebermaknaan ini juga yang kemudian memunculkan keterlibatan dalam pekerjaan tidak hanya dari secara kognitif saja tetapi juga secara afeksi dan perilaku.

\section{SARAN}

Berdasarkan penelitian yang telah dilakukan dan temuan hasil penelitian, ada beberapa saran yang dapat penulis sampaikan sehubungan dengan proses penelitian dan hasil yang diperoleh. Adapun saran-saran tersebut yakni:

\section{Perusahaan}

Bagi PTBA diharapkan dapat terus mengembangkan program-program untuk mempertahankan dan meningkatkan work engagement dan spiritualitas karyawan yang telah ada, tujuannya adalah untuk meningkatkan kinerja dan kesejahteraan karyawan yang akan berdampak pada produktifitas perusahaan secara keseluruhan.

\section{Peneliti Selanjutnya}

Bagi peneliti selanjutnya yang tertarik dengan topik yang relatif sama, maka ada beberapa saran yang dapat penulis berikan, yakni: bila tertarik untuk menggunakan variabel work engagement dan spiritualitas sebagai variabel penelitian dapat memperluas cakupan subjek penelitian pada jenis profesi/pekerjaan yang lain agar generalitas hasil penelitian dapatlebih diperluas. Selain itu, untuk memperkaya secara teoritis mengenai kedua variabel ini, peneliti dapat meneliti varabel-variabel lain yang juga ikut mempengaruhi perkembangan dan pembentukannya.

\section{DAFTAR PUSTAKA}

Ashmos, D.P. \& Duchon, D. (2000). Spirtuality at Work: A Conceptualization and Measure. Journal of Management Inquiry, 9, 2, 134-145.

Bakker, A.B., Schaufeli, W.B., Leiter, M.P., \& Taris, T.W., (2008). Employee engagement: An Emerging Concept in Occupational Health Psychology. Work and Stress. 22, 187-200.

Bakker, A.B., \& Leiter, M.P. 2010. Employee engagement: A Handbook of Essential Theory and Research. New York: Psychology Press.

Bates, R. M. (2004). Getting Engagement. HR Magazine, Vol. 49, No. 2, pp. 44-51.

Harter, J.K., Schmidt, F.L., \& Hayes, T. L. (2002). Business-unit level relationship between employee satisfaction, employee engagement, and business outcomes: A meta- 
analysis. Journal of Applied Psychology, 87, 268-279.

Hawley, J. (1993). Reawekening the Spirit in

Work: The Power of Dharmic

Management. San Fransisco: Berret-

Koehler.

Heaton, D.P., Schmidt-Wilk, J., \& Travis, F. (2004). Constructs, Methods, and Measures for Reasearching Spirituality in Organizations. Journal of Organizational Change Management, $17,1,62-82$.

Khasawneh, S. (2011). Cutting-edge Panacea of the Twenty-First Century. International Journal of Education Management, 25, 7, 687-700.

King, J.E., \& Crowther, M.R. (2004). The Measurement of Religiosity an Sirituality Examples and Issues from Psychology. Journal of Organizational Change Management, 17, 1, 26-42.

Litzey, C. (2003). Spirituality in The Workplace and The implications It has

On Employees and Organizations, 2008, 29 Juli.

Milliman, J., Czaplewski, A.J., \& Ferguson, J. (2003). Workplace Spirituality and Employee Work Attitudes: An Exploratory Emperical Assessment. Journal of Organizational Change Management, 16, 4, 427-447.

Mitroff, I.I., \& Denton, E.A. (1999). Study of Spirituality in the Workplace. Sloan Management Review, Summer, 40, 4, 83-92.

Neal, J.A., \& Biberman, J. (2003). Reasearch That Matters; Helping Organizations Integrate Spiritual Values and Practices. Journal of Organizatinal Change Management. 17, 1, 7-10.

PT. Bukit Asam, Persero. (2015). Annual Report PTBA. http:/www.ptba.co.id, Jakarta: PT. Bukit Asam, Persero.
Rego, Armenio dan Cunha, Migiel Pina. (2008). "Workplace Spritituality and Organizational Commitment: an empirical study." Journal of Organizational Change Management, 21(1): 53-75.

Samiyanto. (2011). Konstrak Spiritualitas dan Pengaruhnya terhadap Psychological capital, Servant Leadership, dan Kinerja Manajer. Disertasi. Yogyakarta: Universitas Gadjah Mada.

Seligman, M.E.P. (2005). Positive Psychology, Positive Prevention, and Positive Therapy. Oxford University Press.

Seligman, M. E. P. \& Steen, T. (2005). Making people happier: a randomized controlled study of exercises that build positive emotion, engagement, and meaning. Am. Psychol. (Submitted.)

Seligman, M.E.P., \& Csikszentmihalyi. (2000). Positive Psychology: An Introduction. American Psycologist, 55, 5-14.

Schaufeli, W.B., \& Salanova, M. (2008). Enhancing Employee engagement throught he Management of Human Resouces. Educational and Psychological Measurement, 66, 701716.

Schaufeli, W.B., \& Bakker, A.B. (2003). Ultrecht Employee engagement Scale: Preliminary Manual. Occupational Healthy Psychology Unit. Ultrecht University.

Simamora, H. (2004). Manajemen Sumber Daya Manusia. Jakarta: LP3ES Indonesia.

Srinivasan, M.S. (2007). The Meeting of Business and Spirituality: Its Evolutionary Significance. Journal of Human Values, 9, 65-73. 
32| PSIKIS-Jurnal Psikologi Islami Vol. 3 No. 1 Juni 2017

Internet:

http:/www.ptba.co.id. Diunduh pada tanggal 6 Oktober 2016.

http://www.indonesia-

investments.com/. Diunduh pada tanggal 7 Oktober 2016. 